\title{
Multimodal Analysis in Developing EFL Students' ESP Listening Skill in Civil Engineering
}

\author{
Yusnimar ${ }^{1}$, Ernawati Br Surbakti ${ }^{2}$, Ismaniar Isa ${ }^{3}$ \\ \{yusnimar@pnl.ac.id ${ }^{1}$, ernawati@pnl.ac.id ${ }^{2}$, ismaniarisa@pnl.ac.id ${ }^{3}$ \} \\ ${ }^{123}$ Politeknik Negeri Lhokseumawe Lhokseumawe, Aceh, Indonesia
}

\begin{abstract}
Multimodality in teaching listening is applying the combination of more than one semiotic mode analysis the students can use in understanding meaning of language expressed in listening. This study aimed to implement multimodal analysis in teaching ESP listening skill for civil engineering students and analyze whether the use of verbal and visual combined modes helps students in developing their listening skill or not. If so, how video helps students in analyzing the meaning of the words they hear from verbal mode. To accomplish the objectives of the study, data from listening test, interview and class observation were gathered. To analyze the data, both quantitative and qualitative methods were involved. The result showed positive responses from majority of respondents. Multimodality analysis in this study was well implemented. The important point is that the study found multimodal analysis could boost students' ESP listening skill and improve their comprehension. The use of pictures and dynamic pictures in the video really aid the students to understand the meaning of the words they heard. Furthermore, students made a longer list of technical words when they were exposed to verbal and visual combined mode compared to verbal mode only.
\end{abstract}

Keywords - Multimodal analysis, ESP listening skill, verbal and visualcombined mode

\section{Introduction}

Listening skill is a receptive skill that needs comprehension towards the language heard. Teaching listening skill is more challenging than reading skill because in listening one has to be able to understand the spoken language which is different to written language in many ways. Moreover, it is very often we do not have a chance to ask for a repetition when we listen to one's talk. In real life, we listen more than we speak, read and write. That's why when one is failed to listen well, it could lead to misunderstanding which in turn will hurt others and even damage career in workplace. Teaching listening becomes more challenging to students in EFL context because they have almost no expose towards native speakers' pronunciation. Furthermore, in listening class, the students should be able to hear the pronunciation of the words, understand the contextual meaning of the words and sentences they hear. Therefore, EFL learners should be taught in various way in order to help them achieving comprehension in listening and be familiar with native accents. 
In addition, teaching listening skill with a specific language tends to be more challenging because besides mastering the concepts of how language works, teachers also have to analyze the language and comprehend the contextual meaning of words that comes from a disciplinary domain that they are teaching in. It has its own specificity. Teachers are also required to be material provider to ensure that chosen authentic material meets the students' needs. Overcoming teacher's competence gap in subject specialties becomes an issue in this field. In this case, teachers should expose themselves to the knowledge and collect authentic materials in the specified knowledge in order to achieve the learning goal, which is helping students to gain contextual meaning of the lexical used. Extra efforts need to be done by the teachers especially for the lesson plan designing and material development. Collaborate with ESP practitioners as well as make full use of existing resources from technologies will bring a great advantage to a successful teaching learning.

Teaching listening by combining verbal and non verbal mode becomes more popular in modern world of multimedia. With the help of digital technology, teachers are expected to be able to use more than one mode. It could bring more advantages to learners' comprehension. [1] categorized four different levels of communication that contribute meaning: discourse, design, production, and distribution. They explained their concepts of multimodality (language, images, and sound can be used for the same discourse). Furthermore, [2] explained that each medium has its own possibilities and limitations of meaning. Not everything that can be realized in language can also be realized by means of images, or vice versa. As well as a broad cultural congruence, there is significant difference between the two and other semiotic modes,. But language does not have or need angles of vision to achieve perspective, nor does it need spatial dispositions of elements to achieve the meanings of syntactic relations: images have and need both.

Applying these views in language teaching, teachers are required to be well-understood that the use of more than one mode in language teaching could be so useful for the students in analyzing the meaning of the message sent. Mode is used based on purpose. Referring to the theory to apply multimodality analysis in teaching listening, teacher should ensure that the visual mode the learners see should aid them to comprehend the meaning of verbal mode they listen to [3].

In addition, [4] explained that on one level, images can be set to document. In other words, they show particular event, particular people and things. Or in semiotic terminology they denote. So, asking what an image denotes is asking; who and/or what is depicted here? In teaching listening, teachers should make sure the pictures and/or moving pictures used in video denote to the verbal (sounds of language). [5] suggests that teaching ESP listening skill is required to involve a prior knowledge preparation about the topic they will hear in listening lesson, as well as giving a frequent short dictation. It could also be done with the activities such as finding visual aids or draw picture and diagrams associated with the listening topics, designing task-oriented exercise to help student learn listening subconsciously, etc.

Some previous studies have been done to implement multimodal material in language teaching. One of the studies did by [6] to 108 students in a university in China found that multimodal teaching model is more welcomed among students than the traditional one. It also does better than the traditional one in promoting students' intrinsic motivation for English learning, improving students' practical ability to use English and promoting students' autonomous English learning ability. She combined listening and speaking activities and tasks in one lesson and also prepared the students with prior knowledge in reading text before listening and speaking class. Students did activity such as answering some questions, summarizing idea of the materials, doing role play by referring to the video material, writing a song lyric while watching video of a song. In addition, [7] in her study found that the ability in English listening of students was higher than before being taught using the communicative approach whereas the ability in English speaking of students was not different between before 
and after being taught using the communicative approach. However, she did not specify what kind of communicative approach activities helped her Thai students in improving their listening comprehension. Moreover, [8] investigated about autonomous learning activities which involving multimodal concept. She found that multimodal-based autonomous listening teaching mode is popular with most of the students. It improves learner's listening level and multiliteracies.

Furthermore, [9] found that the students who were instructed with multimodality in the setting of autonomous learning of English listening could improve their listening skill. Furthermore, [10] has done a study to investigate how English learners process the text and pictorial information in multimodal reading material (reading-only, reading-while-listening). The study also tested whether any difference level of reading comprehension in the two reading modalities. They found that L2 adult learners got a higher score in reading comprehension test compared to L1 learner. They explained that the eye-tracking technology recorder used in recording the reading activities showed that L2 learners spent more time in analyzing image related to reading text than $\mathrm{L} 1$ learner and it could affect the difference score in the reading test.

The present study aims to implement multimodal analysis in teaching listening and analyze whether the use of verbal and visual combined modes helps students in developing their listening skill or not. If so, how video helps student in analyzing the meaning of the words they hear from verbal mode. The different model of multimodal-based listening in this study was about the listening-tasks, the ESP in Engineering students and video material chosen. Differently what [6], [8] and [9] have done, they applied a multimodal-based listening in the context of autonomous learning. The students were set to freely choose their own learning material. It would have different result compared to appropriate learning material and designedlistening-task prepared by teacher, as what [4] suggest that picture and moving picture used in the video should denote to the verbal. Similarly what [5] suggest about preparation of prior knowledge in pre listening task for ESP context. To be concerned, there is still lack of empirical study about listening activities and materials in ESP context, especially experimental research in Civil Engineering field.

\section{Method}

This study was conducted to utilize the existing resources in technology to help students in developing listening comprehension skill through the ability of understanding the contextual meaning of language used in civil Engineering. The respondents were 22 students of Civil Engineering department in bridge and road concentration, Lhokseumawe State Polytechnic, Aceh, Indonesia. Most of them were still in beginner level of English proficiency, only some of them were in pre-intermediate level. To accomplish the objectives of the study, both quantitative and qualitative analysis were carried out. Data obtained from two cycles of test were tabulated and analyzed in quantitative, while data gathered from the interview was analyzed in qualitative method. In first cycle, students were instructed to listen to verbal mode only and in second cycle, they were instructed to pay attention to two modes: verbal (sounds of language) and visual (video). Before listening, students were already guided to discuss some pre-listening questions in order to reduce cognitive burden. It was done to make sure that the students have a prior knowledge about the topic they would hear in listening test. Data was gathered from listening proficiency test both in the first cycle and second cycle. Then, the score they achieved in two cycles were compared to analyze an increasing point between verbalmode only listening and two semiotic modes. In addition, interview was done after teaching treatment. Taking into account the theory of [1] and [2], the researcher set up some questions for interviewing the students who were exposed to multimodality analysis in listening class. 
The questions are: 1 . How did multimodal analysis help you in comprehending meaning of the technical words during the listening session?; 2. How did listening using the combination of verbal and visual develop your listening skill?; 3. Did the combination of modes: sound, pictures and moving pictures help you to be easier in predicting the meaning of difficult words? If so, in what way?. The result of interview then analyzed using qualitative method. Moreover, classroom observation was also done to observe whether the implementation of multimodal analysis in teaching listening was well-implemented or not.

\section{Result and Discussion}

In first cycle, students were instructed to listen to verbal mode only. Data gathered from the test was the amount of technical word and the meaning of each word students could understand during the listening. The topic was about "the process how to recycle concrete to improve material efficiency and save money on construction works". This is a sort of transactional listening and the students need to listen for detail information in order to be able to make a list of technical terms they heard from the recording. In the second cycle, students were instructed to watch video and pay attention to the pictures and dynamic pictures that assisted with the verbal language produced by the sound in the video. They were guided to combine information from two modes to help them understand the meaning. Students made a list or technical term they heard from the language and making meaning of each word.

The score gathered from cycle 1 and cycle 2 were tabulated in the figure 1 below.

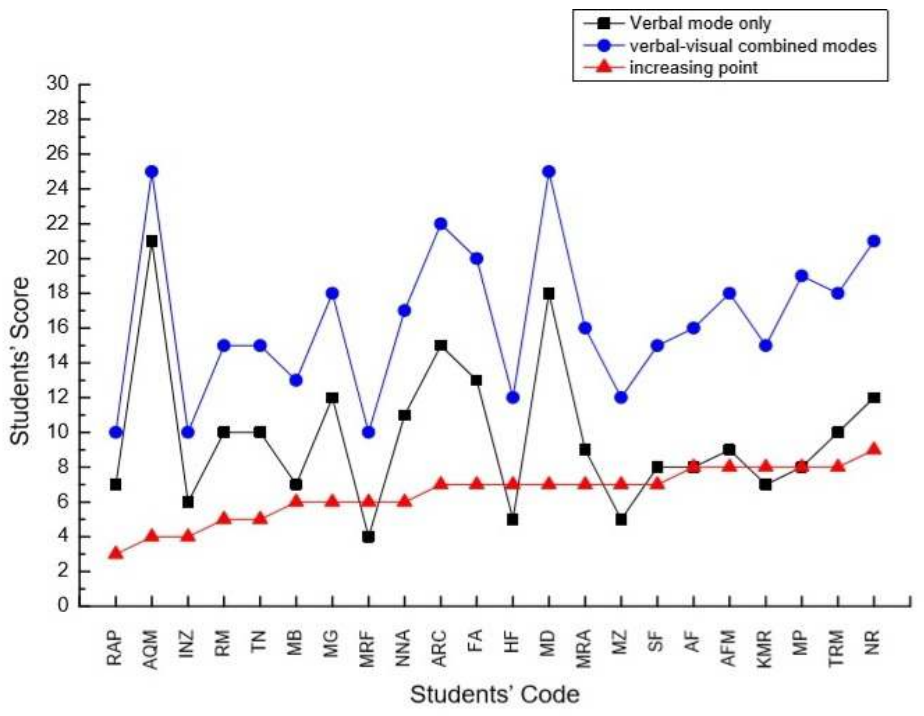

Fig. 1. Students' score in listening with verbal mode

Figure 1. A comparison between students' score in listening with verbal mode only and verbal visual combined mode (x-axis refers to students' codes, $\mathrm{y}$-axis refers to the students' scores). Maximum score $=30$.

Figure 1 showed that there was a significant improvement for majority of students when they were instructed to watch video in their listening class. It can be seen from the longer list of 
technical words they could understand in listening with verbal visual combined modes compared to listening with verbal mode only. Started from 3 to 9 increasing point they achieved. 17 students achieved 6-9 increasing point and others were at 3 to 5 increasing point. It represented that the use of combined modes verbal and visual helped students in developing the listening skill.

To strengthen the research data and specifically to answer the second research question about how combined modes of verbal and visual help students in analyzing the meaning of the words they heard from the listening, researcher used an interview technique to know the perception and experience of the students in the process of listening activities. After teaching treatment, students were interviewed using some structured interview questions. The result showed that, in overall, students responded positively towards the implementation of multimodal analysis in listening class. It improved their listening skill significantly. The detail responses to each question will be discussed, as follow:

1. How did multimodal analysis help you in comprehending meaning of the technical words during the listening session?

Responding to this question, the majority of students stated that the pictures and moving pictures in the video help them in analyzing the meaning of words they heard from the verbal sound. Students analysed meaning of technical words they heard with the support of pictures and moving pictures.

2. How did listening using the combination of verbal and visual develop your listening skill?

Majority of students stated that they found easier to analyze meaning of the words they heard when they exposed to verbal and visual combined mode rather than exposed to verbal mode only. As a result, it improved their listening skill.

3. Did the combination of modes: sound, pictures and moving pictures help you to be easier in predicting the meaning of difficult words? If so, in what way?

Majority of the students felt that by analyzing pictures and the language they firstly could predict context of the utterance used and secondly when words produced in a sentence coming up together with support of pictures and moving pictures students felt it's really helpful for them to be sure with the meaning of the words they heard. For instance, when they listen to the utterance of "reinforcing steel bar or rebar", they saw the moving pictures of engineers were putting the steel in bar form. It made them sure the word they heard is rebar and they also could understand the meaning of rebar because they were exposed to the picture as well. Another example is also the same thing happen when they heard the word demolition site that came up together with the moving picture of demolished building area.

Responding positively to those three questions, only one respondent felt that it was hard for her to concentrate to link between verbal mode and visual mode. This is sort of internal disruptive problem. The majority felt that pictures and moving pictures were very helpful for them in analyzing the meaning of words they heard from the verbal sound. Furthermore, from the class observation it can be seen that the students were enthusiastically paying attention to the listening lesson and highly motivated to get the meaning of the words they heard because there was a picture aid to allow them easier in understanding the meaning. Students analysed meaning of technical words they heard with the support of pictures and moving pictures. It could be concluded that the combined mode of verbal and visual was well implemented. 


\section{Conclusion}

Multimodal analysis is a great choice for language teachers to be used in the teaching. In real life, most of listening contexts involve more than one mode listening, combining verbal and visual modes. Hence, the students need to be exposed to this kind of situation. They will obtain more advantages by exposing themselves to enough exposure of the context. In this study, the students found a greater benefit to develop their listening skill by applying and experiencing multimodal analysis in the listening lesson. From the results of the study, it could be concluded that multimodality analysis in this study was well implemented. The important point is that the study found multimodal analysis in listening class could boost students' ability in understanding the meaning of transactional listening. The use of pictures and dynamic pictures in the video really aid the students to understand the meaning of the words they heard. Furthermore, students made a longer list of technical words when they were exposed to verbal and visual combined mode compared to when they were exposed to verbal mode only. The findings have shed light our understanding that it is crucial to take into account the appropriate learning material, in this context is pictures in the video should denote to the verbal material. Therefore, it could be suggested that future research about material development for ESP listening in civil engineering would benefit listening lesson because there are still limited resources for video which can be used for ESP listening in civil engineering.

\section{Reference}

[1] Kress, G. and Van Leeuwen, T.: Multimodal Discourse The Modes and Media of Contemporaray Communication. Great Britain: Arnold. 2001

[2] Kress, G. and Van Leeuwen, T.: Reading Images: The Grammar of Visual Design. London: Routledge. 2006

[3] Campoy-Cubillo, M. C. and Querol-Julián, M.: Assessing multimodal listening. In Multimodal Analysis in Academic Settings: From Research to Teaching. London/ New York: Routledge, 193-212. 2015

[4] Machin, D and Mayr, A.: How to Do Critical Discourse Analysis. London: SAGE Publication Ltd. 2012

[5] Sura, N. A.: ESP Listening Comprehension for IT-Students as a Language Skill. Middle-East Journal of Scientific Research. Vol. 13, pp 16-21. 2013

[6] Hong, L.: Application of the Multimodal Discourse Analysis Theory to the Teaching of College English Listening and Speaking. IERI Procedia Vol. 2, pp. 319-324. International Conference on Future Computer Supported Education. 2012

[7] Supharatypthin, D.: Developing Students' Ability in Listening and Speaking English Using the Communicative Approach of Teaching. International Journal of Arts \& Sciences, Vol. 07, No 3, pp.141-149. 2014

[8] Ruan, X.: The Role of Multimodal in Chinese EFL Students' Autonomous Listening Comprehension \& Multiliteracies. Theory and Practice. Language Studies, Vol. 5, No. 3, pp. 549-554. 2015

[9] Jiang, Y.: Validity of multimodality in autonomous learning of listening and speaking. Journal of English Language Teaching and Research, Vol. 7 No 2, pp. 352-35. 2016

[10] Pellicer-Sánchez, A., Tragant, E., Conklin, K., Rodgers, M., Llanes, A., and Serrano, R.: L2 reading and reading-while-listening in multimodal learning conditions: an eye-tracking study. ELT Research Papers. 18.01. British Council. UK. 2018 